\title{
Zakat as an Instrument of Tax Receipts (Interpretive Study on Zakat and Tax Receipts
}

\author{
Ibnu Fajarudin ${ }^{1}$, Rony Wardhana ${ }^{2}$, Rudi Harianto ${ }^{3}$, Nurul Aini ${ }^{4}$, Ariyani ${ }^{5}$ \\ rony.unnar@gmail.com ${ }^{2}$ \\ Universitas Narotama ${ }^{1,3,5}$, Universitas Airlangga ${ }^{2,4}$
}

\begin{abstract}
This research to review zakat as an instrument tax revenue. The purpose of this research to understand and interpret zakat as a tax instrument, especially in increased tax revenue. Data collected from 4 informants who have credibility in the field of zakat and taxation. Analysis techniques are used with phenomenological approach. The result of finding at this result indicated zakat is not a tax instrument. This is because there is a clear difference between zakat and tax although also there are similarities between zakat and tax. Other finding indicated the purpose of zakat and purpose of tax in harmony, namely to justice and prosperity for the community. In addition, also there is the "leak" and corruption in tax revenue, so that justice and social prosperity has not been achieved. In addition, zakat has great potential as a source of state revenues are still less explored. The existence of zakat can also be used as a source of financing.
\end{abstract}

Keywords: zakat, instrument, tax, financing.

\section{Pendahuluan}

Banyak orang berusaha menyamakan antara zakat dan pajak.Konsekuensinya ketika seseorang sudah membayar pajak, gugurlah pembayaran zakatnya. Sementara, sebagian lain menolak bahwa zakat sama dengan pajak atau sebagai alternatif dari kewajiban zakat [1]. Zakat dan pajak adalah dua pungutan wajib yang memiliki karakteristik berbeda, Zakat merupakan salah satu ibadah yang mengandung dimensi vertikal sekaligus horisontal, yaitu hubungan antara manusia dengan Tuhan dan hubungan manusia dengan manusia.

Selain adanya persamaan antara zakat dan pajak, zakat juga memiliki potensi yang besar dalam mengentaskan kemiskinan, mengurangi pengangguran, memperkecil kesenjangan antara yang miskin dan kaya, berperan dalam pertumbuhan ekonomi serta meningkatkan potensi pendapatan negara. Namun saat ini pengelolaannya belum maksimal, bahkan sebuah penelitian memperkirakan potensi zakat di Indonesia sebesar Rp.7,5 triliun. Kenyataannya, dana zakat ditambah dengan infak, sedekah, serta wakaf yang dihimpun berkisar Rp.200 miliar pertahun. Itu artinya penghimpunan zakat baru mencapai 2.67 persen dari potensi yang ada [2].

Potensi tersebut harus digali melalui sosialisasi dan diseminasi serta penyadaran akan pentingnya zakat bagi kemaslahatan manusia. Salah satu penggalian potensi berupa pembayaran zakat yang dapat diakui sebagai membayar pajak atau pengurang pajak. Hal ini wajar bila kita membandingkan dinegera Yordania atau Malaysia. Semakin tinggi kesadaran membayar zakat, semakin tinggi pula peningkatan penerimaan pajak. Dengan adanya pengakuan zakat sebagai pengurang pajak atau pembayar pajak, tidak tertutup kemungkinan potensi zakat sekaligus pajak akan mengalami peningkatan. Dalam hal ini, zakat dapat 
digunakan sebagai instrumen pengganti pajak atau pendukung peningkatan pajak. Untuk mewujudkan instrumen tersebut harus didukung oleh aparatur pengelola zakat dan pajak yang kompeten, profesional, dan berintegritas.

Penerimaan pajak yang tidak mengalami peningkatan menunjukkan potensi untuk penggalian pajak dapat dikatakan tidak optimal. Upaya tersebut diperparah lagi dengan kebocoran penerimaan pajak yang masuk ke kas negara. Kurangnya peningkatan penerimaan pajak perlu ada instrumen pendukung lain yang dapat dijadikan sebagai sumber pendapatan negara sekaligus upaya untuk meningkatkan penerimaan pajak. Instrumen pendukung tersebut adalah zakat. Zakat dapat digunakan sebagai instrumen peningkatan penerimaan pajak karena dalam menghitung zakat berdasarkan nilai harta yang terkena nishabnya. Nilai nishab tersebut jarang atau tidak dilakukan perencanaan zakat untuk menghitung harta yang terkena zakat.

Hal ini berbeda dalam menghitung pajak yang dibayar karena terkadang dilakukan perencanaan pajak (tax planning) untuk menghasilkan nilai terendah dalam pembayaran pajak. Berdasarkan nilai nishab tersebut dapat diperkirakan pajak yang dibayar oleh wajib pajak tersebut. Dengan adanya nilai nishab tersebut untuk penghitungan zakat yang dibayar dapat digunakan sebagai instrumen peningkatan penerimaan pajak. Hal ini karena adanya keterbukaan dan kejelasan mengenai jumlah harta yang dimiliki dan diperoleh karena jumlah harta tersebut dapat digunakan sebagai acuan dalam pembayaran pajak oleh wajib pajak. Tujuan penelitian ini adalah untuk memahami dan menginterpretasi zakat sebagai instrumen pajak khususnya dalam peningkatan penerimaan pajak.

\section{Metode}

\subsection{Paradigma dan Pendekatan Penelitian}

Paradigma yang digunakan dalam penelitian ini menggunakan paradigma interpretif memfokuskan pada pola pikir, etika, dan perilaku manusia yang dianggap sebagai suatu tindakan yang melibatkan niat, kesadaran, dan alasan tertentu yang tergantung pada makna dan interpretasi manusia dalam memahami dan memandang fenomena sosial [3]. Pendekatan yang digunakan dalam penelitian ini adalah pendekatan fenomenologi. Pendekatan fenomenologi mencoba menjelaskan atau mengungkap makna konsep atau fenomena pengalaman yang didasari oleh kesadaran yang terjadi pada beberapa individu.

2.2 Informan

Informan yang dipilih adalah orang pribadi muslim yang mengerti atau ahli masalah perpajakan. Dalam hal ini, informan adalah praktisi perpajakan serta orang yang taat beragama dan selalu menunaikan zakat. Peneliti menginginkan adanya tanggapan, pandangan, reaksi, serta interpretasi atas zakat sebagai instrumen penerimaan pajak dari wajib pajak guna mempertajam data yang diperoleh.

2.3 Teknik Pengumpulan Data

Teknik pengumpulan data dilakukan dengan survei pendahuluan, survei kepustakaan, dan pengumpulan data di lapangan dilakukan dengan observasi melibat, wawancara mendalam, dan dokumentasi.

Teknik Analisis Data

Langkah-langkah teknik analisis data pada pendekatan fenomenologi, adalah sebagai berikut [4]:

1. Peneliti memulai mengorganisasikan semua data atau gambaran menyeluruh tentang fenomena pengalaman yang telah dikumpulkan. 
2. Membaca data secara keseluruhan dan membuat catatan pinggir mengenai data yang dianggap penting.

3. Menemukan dan mengelompokkan makna pernyataan dengan melakukan horizonaliting yaitu setiap pernyataan pada awalnya diperlakukan memiliki nilai yang sama. Selanjutnya pernyataan yang tidak relevan dengan topik pertanyaan maupun pernyataan yang bersifat repetitif dihilangkan sehingga yang tersisa hanya horizons (arti tekstural dan unsur pembentuk atau pembentuk dari phenomenon yang tidak mengalami penyimpangan).

4. Pernyataan tersebut kemudian dikumpulkan ke dalam unit makna lalu ditulis gambaran tentang bagaimana pengalaman tersebut terjadi.

5. Selanjutnya peneliti mengembangkan uraian secara keseluruhan dari fenomena sehingga menemukan esensi dari fenomena tersebut. Kemudian peneliti mengembangkan textural description (mengenai fenomena yang terjadi pada informan) dan structural description (yang menjelaskan bagaimana fenomena itu terjadi).

6. Peneliti kemudian memberikan penjelasan secara naratif mengenai esensi dari fenomena yang diteliti dan mendapatkan makna pengalaman informan mengenai fenomena tersebut.

Peneliti membuat laporan pengalaman setiap informan, setelah itu membuat tulisan gabungan dari gambaran-gambaran tersebut.

\section{Pembahasan}

Tujuan pajak yang dipungut oleh pemerintah digunakan untuk keadilan dan kemakmuran masyarakat. Hal ini sebagaimana yang dinyatakan oleh HS sebagai berikut:

"Tujuan bikin negara dan pemerintahan, secara gampangnya negara bisa adil dan makmur".

Tujuan tersebut selaras dengan fungsi pajak sebagai fungsi regulerend, yaitu sebagai alat untuk mengatur atau melaksanakan kebijaksanaan pemerintah dalam bidang sosial dan ekonomi. Dalam bidang sosial berupa pemerataan kemakmuran, yaitu tercapainya keadilan. Konteks keadilan dalam hal ini bukan sama rasa dan sama rata, tetapi siapa yang melakukan upaya lebih, dia berhak mendapatkan sesuatu lebih tersebut. Dengan adanya hal, tersebut kesenjangan antara yang kaya dan miskin dapat diminimalisasi tanpa membatasi kreatifitas masyarakat untuk mendapatkan sesuatu yang lebih. Dalam bidang ekonomi berupa peningkatan kemakmuran. Adanya keselarasan fungsi dan tujuan tersebut, bukan hanya meminimalisasi kesenjangan antara yang kaya dan miskin, tetapi juga meningkatkan pendapatan bagi si miskin dan si kaya untuk meningkatkan kemakmuran. Pernyataan tersebut juga sesuai dengan teori asas daya beli, yaitu daya beli dari rumah tangga dialihkan ke negara, selanjutnya disalurkan kembali ke masyarakat dalam bentuk pemeliharaan kesejahteraan bersama. Hal tersebut senada dengan ungkapan oleh SG sebagai berikut:

"Dengan demikian zakat itu juga untuk menyejahterakan mereka juga ... kawan - kawan kita dari pemeluk agama lain... saya yakin dengan cara perubahan zakat, itu justru percepatan pembangunan".

Pernyataan tersebut sesuai dengan Rahman [5] yang menyatakan zakat mencegah segala pengaruh yang menyebabkan terhambatnya pertumbuhan ekonomi, sebaliknya mendorong tercapainya kemajuan ekonomi dan mempersempit ketimpangan ekonomi. Tujuan negara terkait fungsi pajak juga selaras dengan tujuan zakat, yaitu untuk menyejahterakan mereka 
(nonmuslim), tidak hanya muslim saja. Bahkan, dengan cara perubahan zakat dapat mempercepat pembangunan. Ini menunjukkan tujuan zakat dan pajak menunjukkan kesamaan, yaitu dalam rangka menyejahterakan masyarakat.

Tujuan keadilan dan kemakmuran tersebut, saat ini masih belum dapat dicapai. Hal ini sebagaimana dinyatakan oleh HS sebagai berikut.

"Sudah berapa puluh tahun negara kita ini merdeka, adil makmur belum tercapai, hal ini karena tidak memakai hukumnya Tuhan, tetapi memakai hukumnya manusia. Kalau memakai hukumnya Tuhan iya tho, adil makmur itu tercapai, kalau begini terus selamanya tidak tercapai adil makmur".

Tujuan pajak untuk mencapai keadilan dan kemakmuran belum dapat dikatakan tercapai. Ungkapan tersebut selaras dengan ungkapan yang dinyatakan oleh SG sebagai berikut.

"Kalau kita mau jujur sudah berapa puluh tahun sih dengan dasar pajak itu, ternyata kita tidak berhasil"'.

Hal ini karena hukum yang digunakan hukum yang dibuat oleh manusia bukan hukum Tuhan. Kalau hukum yang dibuat manusia, manusia yang melanggar hukum tersebut tidak berdosa, sebagai misal pembayar pajak tidak membayar pajak itu tidak berdosa. Ini berbeda dengan kalau tidak membayar zakat, manusia tersebut akan mendapat dosa. Hal tersebut sesuai dengan pernyataan HS sebagai berikut.

"Kalau menurut saya tidak membayar (pajak) tidak berdosa kalau dipenjara itu urusan lain, itu hukumannya manusia dipenjara tapi kalau namanya zakat dan sebagainya yang tercantum dalam hukum Tuhan membayar dapat pahala tidak membayar ada sanksinya, itu pelanggaran dalam Islam, itu dosa gak bayar, itu dosa”.

Adanya pernyataan tersebut, zakat dapat digunakan sebagai pendapatan negara tetapi zakat tidak dapat digunakan sebagai instrumen peningkatan penerimaan pajak. Hal ini karena zakat tidak mempunyai keterkaitan dengan pajak karena zakat terkait dengan hukum Tuhan, sedangkan pajak terkait dengan hukum manusia. Zakat dapat dikatakan sebagai instrumen pajak, kalau pajak juga mempunyai keterkaitan dengan hukum Tuhan. Dalam hal ini, hukum Tuhan adalah hukum yang diatur dalam kitab suci. Bahkan, adanya kecenderungan pajak mengalami penurunan karena tidak ada sanksi dengan hukum Tuhan, tetapi hanya sanksi dengan hukum manusia berupa hukuman badan bagi yang tidak membayar pajak. Hal senada tersebut juga diungkapkan oleh SW sebagai berikut.

"Umpamanya kalo dah bayar zakat gak bayar pajak disalahkan oleh Negara, nanti kalo bayar pajak dak bayar zakat takut Tuhan, itu masalahnya".

Hal tersebut menguatkan bahwa zakat bukan instrumen untuk peningkatan penerimaan pajak, tetapi sebagai salah satu sumber pendapatan negara. Dalam hal ini terdapat garis tegas bahwa pajak keterkaitannya dengan negara, sedangkan zakat keterkaitan dengan Tuhan. Selain itu, pajak mempunyai keterkaitan dengan hukum manusia, sedangkan zakat mempunyai keterkaitan dengan manusia sekaligus dengan Tuhan. Hal tersebut diperjelas dengan adanya sanksi oleh negara terkait dengan pajak, sedangkan terkait zakat adanya sanksi dari Tuhan.

Pajak tidak mengalami peningkatan tidak saja karena wajib pajak tidak membayar pajak, tetapi juga karena korupsi pajak yang dilakukan oleh pihak - pihak terkait. Hal ini sebagaimana dinyatakan oleh HS sebagai berikuti:

"Tidak bisa begitu disalahkan mereka - mereka yang terlibat dalam korupsi pajak, baik yang narik maupun yang bayar, itu karena bukan suatu kewajiban yang harus yang mengandung dosa, mengambil dosa mengambil hak orang lain, tetapi secara prinsipiil barang itu tidak ada dalam hukum Tuhan, kecuali bagi mereka yang nonmuslim"

Penerimaan pajak kurang mengalami peningkatan karena adanya "korupsi" yang dilakukan oleh para wajib pajak dan fiskus. Wajib pajak melakukan korupsi dengan upaya tax 
avoidance berupa upaya meringankan beban pajak dengan tidak melanggar undang - undang, semisal melakukan perencanaan pajak (tax planning) dan tax evasion berupa usaha meringankan beban pajak dengan cara-cara melanggar undang-undang, semisal melaporkan yang tidak sesuai dengan semestinya. Fiskus melakukan korupsi pajak dengan upaya mengalihkan sebagian penerimaan pajak ke kantong pribadinya. Hal ini didukung dengan adanya bukti berupa kasus-kasus yang melibatkan aparat pajak, seperti kasus Gayus Tambunan, kasus Dhanny W, kasus Tomy Hendratno, dan kasus - kasus lainnya. Adanya "korupsi" pajak yang semarak tersebut karena perbuatan tersebut tidak mengandung dosa. Ini karena tidak mengambil hak orang dan tidak ada dalam hukum Tuhan, kecuali bagi mereka yang nonmuslim. Hal ini berbeda dengan zakat, apabila zakat tersebut di "korupsi" akan menanggung dosa karena zakat tersebut hak atas orang lain, yaitu hak orang yang menerima zakat tersebut berupa 8 asnaf. Hal tersebut senada dengan pernyataan SG sebagai berikut ini.

"Kalau kita mau jujur berapa puluh tahun merdeka, ternyata pendanaan seperti itu banyak bocornya, terlalu banyak bocornya"

Adanya "kebocoran" dalam pendanaan yang bersumber dari pajak membuat penerimaan pajak kurang mengalami peningkatan secara signifikan. Hal tersebut menimbulkan pandangan masyarakat enggan untuk membayar pajak. Bahkan adanya fatwa oleh Pengurus Besar Nadhlatul Ulama untuk tidak membayar pajak, kalau penerimaan pajak mengalami "kebocoran". dikorupsi oleh para aparatur pajak dan tidak untuk kepentingan rakyat. Hal tersebut juga senada dengan pernyataan Mantan Menteri Keuangan bahwa jumlah pajak yang masuk ke kas negara tidak lebih dari 50\%. Korupsi dan kebocoran tersebut dapat ditangani dengan zakat sesuai ungkapan SG sebagai berikut:

"Sekarang korupsi marak tertangani dengan adanya zakat, apalagi kalau sudah ada wadah yang betul-betul sudah permanen dan dilegalkan yang sifatnya nasional".

Dengan zakat, korupsi dapat tertangani karena zakat tidak hanya berkaitan dengan manusia atau negara, tetapi juga dengan Tuhan. Apalagi zakat tersebut diwadahi dalam lembaga yang permanen, legal, dan nasional, maka korupsi akan terminimalisasi.

Zakat dapat digunakan sebagai sumber pendapatan negara selain pajak. Hal ini sebagaimana diungkapkan oleh HS sebagai berikut.

"Berkaitan negara kekurangan dana, misalnya tuk membiayai operasional pemerintah, zakat bisa dipakai untuk itu. Ini dibuktikan dengan negara Yordania dan Iran yang ekonominya ditopang oleh zakat".

Pernyataan tersebut menunjukkan zakat dapat digunakan untuk membiayai operasional pemerintah. Hal tersebut juga menguatkan bahwa zakat bukan sebagai instrumen penerimaan pajak, tetapi sebagai pendapatan negara. Ini menunjukkan bahwa zakat dapat berfungsi sebagai penyangga operasional pemerintah kalau penerimaan pajak tidak mampu untuk membiayai operasional pemerintah. Ungkapan tersebut senada dengan pernyataan yang diungkapkan oleh SG sebagai berikut.

"Ambillah ...... diantaranya untuk membersihkan disamping itu juga ada nilai - nilai lain atau tujuan lain sebagai sumber pembiayaan.... zakat itu potensinya besar, saya kira dengan sistem ZIS terdapat dua keuntungan, disamping tujuan duniawi juga tujuan ukhrawi, ini perintah kok.... terdapat zakat pertanian, zakat perdagangan, dan lain - lain tinggal kemauan saja".

Ini menunjukkan zakat tidak hanya membersihkan kekayaan bagi pembayar zakat, tetapi secara makro zakat juga sebagai sumber pembiayaan, baik pembiayaan operasional maupun pembiayaan modal. Bahkan potensi zakat besar. Ini ditunjukkan dengan sebuah penelitian yang memperkirakan zakat di Indonesia sebesar Rp 7,5 triliun, tetapi yang baru dihimpun sekitar Rp 200 miliar. Ini artinya penghimpunan baru mencapai 2,67 persen dari potensial 
yang ada [6]. Selain itu, pernyataan ini diperkuat oleh penelitian Indrijatiningrum (2010) yang menyatakan potensi zakat masih terbuka luas dengan realisasi sekitar 1,6 persen dari potensi zakat penghasilan/profesi. Selain itu, potensi zakat penghasilan/profesi masih dapat digali dari 16,91 persen jumlah tenaga kerja di Indonesia atau sebanyak 15.847 .072 orang muzakki. Selain itu, potensi zakat tidak hanya pada zakat fitrah dan zakat maal, tetapi juga pada zakat pertanian, zakat pertambangan, zakat binatang, dan zakat - zakat lainnya. Ungkapan tersebut diperkuat oleh pernyataan HA sebagai berikut.

"Kepemerintahan membutuhkan segala macam biaya untuk menata masyarakatnya, persaingan dengan negara lain, sosial dan pengaturan lainnya"

Dalam kepemerintahan dibutuhkan segala macam biaya, tidak hanya pajak saja, tetapi juga zakat untuk mengatur pemerintah dalam menata masyarakatnya, persaingan dengan negara lain, sosial, dan pengaturan lainnya. Pernyataan tersebut juga memperkuat bahwa zakat bukan sebagai instrumen penerimaan pajak, tetapi zakat dan pajak digunakan sebagai pembiayaan. Oleh karena itu, perlu peran pemerintah sebagai panitia zakat (amil) untuk mengelola zakat tersebut. Hal ini sebagaimana dinyatakan oleh HS sebagai berikut.

"Bagian pemerintah di zakat sebagai amil ya mengurusnya. Pengurusnya, pertama tidak dikenakan harus bayar pajak bahkan malah dapat. Pemerintah itu amil karena yang ngurusi semua pemasukan tidak harus dikeluarkan semuanya, bahkan harus ada semacam baitul maal, perbendaharaan negara".

Pemerintah sebagai amil harus mengelola zakat. Dalam mengelola zakat tersebut tidak ada pajak yang harus dibayar malah pengelolanya mendapatkan zakat tanpa dipotong pajak sama sekali. Dalam mengelola tersebut diupayakan adanya surplus dan surplus tersebut ditempatkan pada baitul maal. Dalam hal ini, fungsi baitul maal sebagai cadangan atau untuk berjaga - jaga terkait operasional pemerintah sekaligus untuk membantu kebutuhan masyarakat yang membutuhkan pendanaan. Apabila baitul maal tidak ada, kekurangan operasional pemerintah selama ini lebih banyak dilakukan dengan melakukan pinjaman melalui utang. Hal tersebut sebagaimana dinyatakan oleh HS sebagai berikut.

"Adanya baitul maal sebagai tempat surplus kekayaan, malah utang gak perlu, utang tersebut malah tidak menjamin keamanan dan ketenangan"

Adanya pinjaman utang untuk menutupi pengeluaran membuat tidak adanya keamanan dan ketenangan. Negara yang mengandalkan utang oleh negara lain biasanya didikte oleh negara tersebut sehingga keamanan khususnya ketenangan negara tersebut jadi terganggu. Apalagi kalau adanya utang dengan syarat yang beraneka ragam dan dengan tingkat bunga yang tinggi, hal ini jelas akan membuat ketidaktenangan negara tersebut dalam mengelola negaranya. Selain itu, juga adanya kerancuan dalam sistem negara ini, hal ini sebagaimana diungkapkan oleh HS sebagai berikut:

"Sistem negara kita rancu, dari segi zakat dari segi pajak rancu karena mayoritas rakyatnya beragama Islam dan mereka berkewajiban membayar zakat tapi dikenakan pajak, lha pajak itu tempatnya dimana lha ini khan rancu, dobel jadinya, wis bayar zakat mestinya harus bebas dan memang tidak dikenakan pajak"

Bagi rakyatnya yang beragama Islam, mereka yang berkewajiban membayar zakat seharusnya tidak dikenakan pajak. Hal ini karena zakat merupakan sejenis pajak karena zakat memenuhi beberapa persyaratan perpajakan, seperti pembayaran yang diwajibkan, tidak ada balasan atau imbalan, dan memiliki tujuan kemasyarakatan, ekonomi, politik, dan keuangan [7]. Zakat bukanlah pajak dalam pengertian biasa, tetapi merupakan pajak khusus yang hanya diwajibkan kepada umat Islam. Hal tersebut juga memperkuat bahwa zakat bukan sebagai instrumen penerimaan pajak walaupun mempunyai karakteristik yang sama dengan pajak. 
Zakat dan pajak tersebut sebagai sumber pendapatan negara. Pernyataan tersebut agak sependapat dengan ungkapan yang dikemukakan oleh HA sebagai berikut:

"Seumpama dirinya sendiri, aku sudah bayar zakat kok tarik pajak, kalau berani tidak apa-apa"

Bagi masyarakat yang berani protes dengan menyatakan saya sudah wajib bayar zakat, tetapi masih ditarik pajak, itu tidak apa-apa. Akan tetapi pernyataan dan perbuatan yang dilakukan harus berani menerima konsekuensi dengan undang-undang yang dijalankan di negara ini. berikut.

Ungkapan tersebut agak berbeda dengan ungkapan yang dikemukakan oleh HA sebagai

"Zakat itu kan sosial, sedangkan pajak itu bukan, sebenarnya kedua hal tersebut tidak bermasalah"

Zakat dalam konteks ini berkaitan dengan sosial, yaitu hubungan antara manusia yang berhak mengeluarkan zakat dengan para penerima yang berhak. Sementara, pajak konteksnya tidak berkaitan dengan sosial, yaitu bisnis dimana individu dan badan usaha yang mendapatkan keuntungan harus mengeluarkan pajak. Ini juga menguatkan bahwa zakat bukan sebagai instrumen penerimaan pajak karenaberbeda konteks kedua hal tersebut. Kedua hal tersebut tidak terdapat masalah, malah adanya kesinergian antara sosial dan bisnis. Pernyataan ini diperkuat dengan ungkapan yang dikemukakan oleh HA sebagai berikut.

"urusan seperti itu, zakat dan pajak, zakat itu adalah intern karena kita beragama Islam tidak boleh meninggalkan zakat, kalau pajak karena kita bertempat di negara yang mempunyai pengaturan seperti itu".

Dalam hal pajak dan zakat mempunyai perbedaan, baik terkait dengan intern keagamaan kita maupun pengaturan yang dijalankan oleh pemerintahan. Ini juga memperkuat bahwa zakat bukan sebagai instrumen pajak terkait dengan intern keagamaan karena bagi umat Islam, zakat merupakan kewajiban bagi pemeluknya, sedangkan bagi umat non Islam, zakat bukan merupakan kewajiban. Pernyataan tersebut diperkuat lagi dengan ungkapan HA sebagai berikut.

"kalau pajak itu diniatkan sebagai zakat, maka gugurlah kewajiban membayar zakat tetapi itu tingkatan rendah"

Ini menunjukkan pajak dapat digunakan sebagai pengganti zakat bukan sebagai instrumen penerimaan pajak, tetapi tingkatan tersebut dapat dikatakan tingkatannya rendah. Hal ini karena zakat tidak hanya hubungan antara manusia dengan manusia, tetapi juga hubungan antara manusia dengan Tuhannya. Kalau rakyatnya wajib membayar zakat dan pajak, itu berarti adanya pungutan ganda. Hal tersebut akan memberatkan rakyat kalau keduanya menjadi kewajiban. Selain itu, juga adanya kekurangmengertian pemerintah mengenai hal tersebut. Hal ini dinyatakan oleh HS sebagai berikut.

"Pemerintah mudah-mudahan mengerti menggunakan hukum pajak, cuma saya gak tahu kok kenapa punya pengertian tidak dilaksanakan, gampangnya begitu”.

Pemerintah sebenarnya mengerti mengenai hukum pajak tersebut yaitu pungutan yang bersifat ganda tidak diperkenankan. Adanya kewajiban membayar zakat sekaligus membayar pajak sebenarnya merupakan pungutan yang bersifat ganda, tetapi hal tersebut tidak diimplementasikan. Akhirnya rakyat yang wajib membayar zakat, tetap juga dikenakan wajib pajak. Ini juga menunjukkan bahwa zakat bukan sebagai instrumen pajak. Pungutan ganda tersebut dapat dikenakan kepada rakyatnya apabila negara dalam keadaan darurat. Hal ini sebagaimana dinyatakan oleh HS sebagai berikut.

"Pungutan ganda berupa zakat dan pajak tersebut dapat dikenakan kalau kondisinya darurat, wong negara ini gak darurat kok" 
Pungutan bersifat ganda berupa wajib zakat dan wajib pajak dapat dikenakan pada rakyatnya, apabila kondisi negara darurat, semisal adanya ancaman kelaparan, peperangan, dan lain - lain. Apabila kondisi negaranya tidak darurat pungutan ganda tersebut seharusnya tidak dapat dikenakan. Hal tersebut tidak hanya dipikirkan oleh pemerintah, tetapi juga lembaga keagamaan yang terkait dengan zakat, semisal Majelis Ulama Indonesia juga harus memikirkan hal tersebut. Hal ini sebagaimana dinyatakan oleh HS sebagai berikut.

"MUI sebagai lembaga resmi yang diakui pemerintah harus memikirkan hal - hal seperti ini, bukannya baru kalau ada masalah, masalah - masalah ringan, jadi mutunya tidak bisa dijamin".

Pungutan bersifat ganda dikenakan apabila negara dalam keadaan darurat tidak hanya diperhatikan oleh pemerintah, tetapi juga oleh lembaga keagamaan yang diakui pemerintah, seperti MUI. Dalam hal ini, MUI tidak hanya berpikir kalau ada masalah saja, tetapi juga mengantisipasi kalau ada masalah atau mengkaji masalah-masalah yang timbul pada masa yang akan datang. Begitu pula, masalah-masalah yang harus diperhatikan oleh MUI bukannya yang ringan saja, semisal masalah tembakau atau rokok. Apabila MUI tidak memikirkan masalah-masalah yang timbul pada masa datang dan hanya masalah ringan, maka lembaga tersebut mutunya tidak bisa dijamin atau dipertanyakan.

Zakat dan pajak tidak hanya dikenakan pada perorangan, tetapi juga pada perusahaan atau badan usaha. Hal ini sebagaimana diungkapkan oleh HS sebagai berikut.

"Zakat dan pajak juga dikenakan pada badan usaha. Kalau pemegang sahamnya milik orang Islam ditawari, kamu milih bayar pajak atau zakat".

Perusahaan yang terkena zakat dan pajak, kalau pemegang sahamnya orang Islam harus ditawari milih di antara kedua hal tersebut. Apabila pemegang saham milih wajib bayar zakat, dia seharusnya terbebas untuk bayar pajak. Ini juga memperkuat bahwa zakat bukan sebagai instrumen penerimaan pajak. Dalam konteks badan usaha di Indonesia, maka badan usaha di Indonesia akan milih bayar pajak terlepas pemegang sahamnya orang muslim atau bukan nonmuslim. Apabila hanya membayar zakat tanpa membayar pajak, badan usaha akan dikenakan tuntutan atas pajak beserta dendanya.

\section{Kesimpulan}

Berdasarkan hasil dan pembahasan tersebut,dapat disimpulkan tujuan pajak dan tujuan zakat selaras, yaitu untuk keadilan dan kemakmuran masyarakat, tetapi tujuan tersebut saat ini masih belum tercapai. Hal ini karena zakat tidak dapat digunakan sebagai instrumen peningkatan pajak, tetapi sebagai sumber pendapatan negara. Di sisi lainnya, pajak dikorupsi dan mengalami "kebocoran" dalam penerimaan pajak. Zakat tidak dapat digunakan sebagai instrumen penerimaan pajak karena ada perbedaan secara jelas antara zakat dan pajak. Zakat mempunyai potensi besar sebagai sumber penerimaan negara. Ini ditunjukkan penghimpunan zakat hanya sebesar 2,67 persen dan masih adanya potensi 16,91 persen dari jumlah tenaga kerja di Indonesia. Selain itu, masih ada berbagai macam zakat yang kurang tergali diluar zakat fitrah dan zakat maal. Zakat juga dapat digunakan untuk pembiayaan dalam pemerintahan. Oleh karena itu, perlu panitia zakat (amil) serta peran Majelis Ulama Indonesia (MUI) dalam mengelola zakat tersebut. Zakat juga tidak hanya dikenakan pada perorangan, tetapi juga pada perusahaan atau badan usaha.

\section{References}


[1] UIN Syarif Hidayatullah, 2010, Perbedaan dan Persamaan antara Zakat dan Pajak Manajemen Zakat Online, diunduh 26 Februari 2010..

[2] Farid Wajdi, 2008, dalam Kajian Penerapan Zakat,Mengukur Manajemen Zakat di Indonesia, Manajemen Zakat Online (17 Maret 2011).

[3] Bungin, Burhan, 2007, Metodologi Penelitian Kualitatif: Aktualisasi Metodologis ke Arah Ragam Varian Kontemporer. PT. Rajagrafindo Persada. Jakarta.

[4] Creswell, J. W, 2007. Kualitatif Inquiry and Research Design. Sage Publication, Inc.

[5] Rahman, Afzalur, 2002, Doktrin Ekonomi Islam. Edisi Kedua. Penerbit Dana Bhakti Wakaf. Yogyakarta.

[6] Farid Wajdi, 2008, dalam Kajian Penerapan Zakat,Mengukur Manajemen Zakat di Indonesia, Manajemen Zakat Online (17 Maret 2011).

[7] Yusuf Qordhowi, 1997, Norma dan Etika Ekonomi Islam, Gema Insani Pres. 